Abstracta Iranica Abstanica

Revue bibliographique pour le domaine irano-aryen

Volume 34-35-36 | 2017

Comptes rendus des publications de 2011-2013

\title{
Laetitia Nanquette. Orientalism versus Occidentalism: Literary and Cultural Imaging between France and Iran since the Islamic Revolution
}

Julie Duvigneau

\section{OpenEdition}

Journals

Édition électronique

URL : http://journals.openedition.org/abstractairanica/42776

DOI : 10.4000/abstractairanica.42776

ISSN : 1961-960X

Éditeur :

CNRS (UMR 7528 Mondes iraniens et indiens), Éditions de l'IFRI

Référence électronique

Julie Duvigneau, « Laetitia Nanquette. Orientalism versus Occidentalism: Literary and Cultural Imaging between France and Iran since the Islamic Revolution », Abstracta Iranica [En ligne], Volume 34-35-36 I 2017, document 2, mis en ligne le 30 juillet 2017, consulté le 01 octobre 2020. URL : http:// journals.openedition.org/abstractairanica/42776 ; DOI : https://doi.org/10.4000/abstractairanica. 42776

Ce document a été généré automatiquement le 1 octobre 2020.

Tous droits réservés 


\title{
Laetitia Nanquette. Orientalism versus Occidentalism: Literary and Cultural Imaging between France and Iran since the Islamic Revolution
}

\author{
Julie Duvigneau
}

\section{RÉFÉRENCE}

Laetitia Nanquette. Orientalism versus Occidentalism: Literary and Cultural Imaging between France and Iran since the Islamic Revolution. London / New York, I.B. Tauris, 2013, 252 p.

1 Dans cet ouvrage, issu de sa thèse de doctorat, l'A, chercheuse en littérature persane contemporaine à l'Université de New South Wales de Sydney, livre une étude d'imagologie sur la représentation de l'Iran et de la France dans les littératures des deux pays après la révolution de 1979.

2 L'ambition de l'A est de susciter une prise de conscience et une remise en question des stéréotypes véhiculés de part et d'autre par ces deux pays, à travers leur littérature.

3 L'ouvrage est articulé en cinq mouvements, qui sont autant de catégories de son corpus de plus de quatre-vingt ouvrages : les textes français sur l'Iran, les textes iraniens écrits en français, les textes iraniens sur la France, la littérature persane en exil avant de finir sur les textes français et iraniens hybrides. Ces croisements de regard tous azimuts permettent à l'auteur de s'affranchir des oppositions binaires réductrices comme Orientalisme contre Occidentalisme, le contenu de l'ouvrage dépassant ainsi l'annonce de son titre. 
4 La dernière partie engage également une réflexion prometteuse à propos des effets de la littérature en exil sur l'évolution des formes narratives en Iran.

\section{AUTEURS}

\section{JULIE DUVIGNEAU}

Institut National des Langues et Civilisations Orientales 